\title{
Assessment of Human-Wildlife Conflicts in Poba Reserved Forest, Dhemaji District, Assam (INDIA)
}

\author{
Rajeswar Pegu, Ajit K. Tamuli, Robindra Teron* \\ ${ }^{1}$ Department of Life Science \& Bioinformatics, Assam \\ University- Diphu Campus, Diphu, Karbi Anglong, \\ Assam- 782462
}

Study Area: Poba Reserve Forest, Assam, India

Coordinates: $27^{\circ} 45^{\prime} \mathrm{N} ; 95^{\circ} 20^{\prime} \mathrm{E}$

Key words: Poba RF, Human-wildlife conflict, Crops, Livestock, Conservation.

\section{Abstract}

Human-wildlife conflicts from 1971-2013 in Poba Reserved Forest is presented here. Data collection included interview, records of forest department and participant observation. There is an increasing trend of human-wildlife conflict in Poba RF. Encroachment for agricultural expansion, frequent venturing into forests to collect minor forest products and livestock grazing are major causes of conflicts. Most cases of conflict occurred in forests and crop fields suggesting encroachment and venturing into animal habitat exposed human to conflict with wildlife. Pearson's correlation at 0.01 level of signif icance showed positive correlation between wildlife injured/killed and livestock killed/injured (o.819411) and wildlife injured/killed and property damaged (0.6580o9) but negative correlation between wildlife injured/killed and crop damaged (-0.04104). Crop raiding by wildlife caused considerable damage to crops and property resulting in food insecurity and economic loss to farmers; farmers also suffered economic loss due to livestock lifting by prey animals. Long years of exposure to crop and property loss and risk to life are associated with negative attitude towards wildlife. The present report will be useful in understanding the nature of conflicts and help local forest department in initiating appropriate conservation measures in Poba RF

*Corresponding Author: robin.teron@gmail.com 


\section{Introduction}

Humanwildlife conflict is a global concern having social, cultural, economic and conservation implications. Human-animal conflict has been in existence for as long as humans have existed and wild animals and people have shared the same landscapes and resources (Lamarque et al., 2008). Direct contact with wildlife occurs in both urban and rural areas, but it is generally more common inside and around Protected Areas (Distefano, 2005). Encroachment resulting in habitat overlap of animals with human stands out among the major causes of conflict, creating costs to both residents and wild animals (WPC, 2003). With continuous loss of habitat qualitatively as well as quantitatively, wild animals are forced to extend their range and raid crops to meet their energy requirements (Borah et al., 2005). Human-elephant conflict is a key example of such an interaction in which elephant crop raiding, infrastructural damage and disturbance to daily activities can result in injury or death of people and elephants alike (Hoare, 200o). Elephant incursions into human habitation are not new but have been going on ever since man took to agriculture within elephant habitat (Sukumar, 1994). The wild boar (Sus scrofa), which is one of the most widely distributed large mammals, is also regarded as the most widespread crop pest (Fadeev, 1981; Erkinaro et al., 1982; Sukumar, 1994; Tisdell, 1982). Crop raiding by troops of monkeys is a concern; the animals forcefully enter houses and consume or damage foods. Rodents and other small vertebrates have also been recognized as pest of agriculture that can inflict economic loss to farmers.

Wildlife related crops, property and livestock loss and risk to lives have contributed to negative attitudes towards wildlife around the world (Riley \& Decker, 200o; Sillero-Zubri \& Switzer, 2001; Naughton-Treves \& Treves, 2005; Arjunan et al., 2006). Addressing humanwildlife conflict is among the most challenging issues that conservation practitioners face today (Karanth et al., 2013). With increasing population and pressure on forest ecosystems, human-wildlife conflict is also increasing (Zubiri \& Switzer, 2001). Considering the magnitude of implications of humanwildlife conflicts it is priority to develop effective preventive and mitigation strategies to avoid losses on both sides (i.e., man and animals) (Naughton-Treves, 1998; Woodroffe et al., 2005; Linkie et al., 2007; Treves et al., 2009; Patel \& Dharaiya, 2014).

The objective of this paper is to discuss the causes and implications of human-wildlife conflicts in Poba Reserved Forest (RF), a threatened ecosystem in Dhemaji district of Assam state, during the period from 1971 to 2013. Fringe area of the RF is under intense human habitation and their subsistence largely depends on this forest. Poba RF is the only natural forest and repository of wild plant resources in the entire Jonai Subdivision but its biodiversity has not been scientifically evaluated so far (Pegu et al., 2013). The forest is an important elephant corridor linking the Daying Ering Wildlife Sanctuary (Arunachal Pradesh) and Dibru Saikhowa National Park via the proposed Kobu Chapori Reserve Forest. Since 1972 the forest has been under threats from anthropogenic activities resulting in human-wildlife conflicts and loss of biodiversity but the problems and its implications has not been studied earlier. The forest also faces pressure from collection of minor forest 
products which may soon exceed beyond its carrying capacity of the forest ecosystem. Evaluation of human-wildlife conflict in Poba RF will help to understand subsistence practices of people or communities, their dependence on the forest and identify determinants of conflicts. This in turn will be useful for local forest department in framing conservation policies and for undertaking development activities in Poba RF. To realize our objective we proposed a simple working hypothesis that 'encroachment and venturing into animal habitats (i.e., Poba forest) are major causes of human-wildlife conflicts'.

\section{Materials and Methods:}

Study Area: Poba Reserved Forest (RF) with an area of 10,221 hectares is located between $27^{\circ} 45^{\prime} \mathrm{N}$ latitude and 95ㅜㅇ' ${ }^{\circ}$ longitude in Jonai subdivision of Dhemaji district, Assam (Fig. 1). It is bounded by Daying Ering Wildlife Sanctuary, $\mathrm{NH}^{-52}$ and Arunachal Pradesh in the North, Dibru-Saikhowa National Park and the Siang, Dibang and Lohit rivers in the East, Laly River (referred as Brahmaputra down-

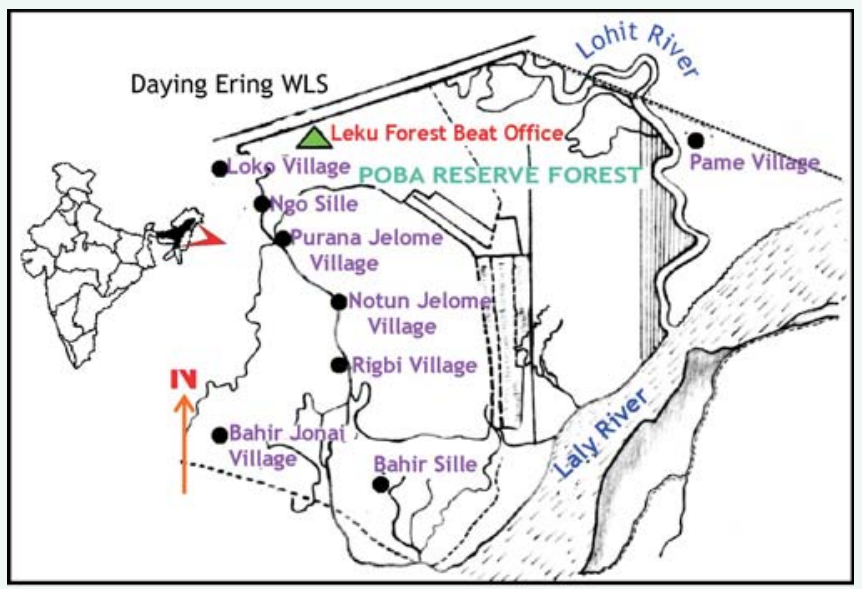

Fig-1: Various villages proximate to Poba Reserve Forest stream) in the South, and a few revenue villages in the West. The Forest receives annual rainfall of $3600 \mathrm{~mm}$ to $4000 \mathrm{~mm}$ and temperature varying from $350 \mathrm{C}$ in summer and $70 \mathrm{C}$ in winter. Fringe area of the RF is under intense human habitation that included villages such as Kemi, Oiramghat, Purona Jelom, Leku, Sirung, Nahor Jelom, Leku Jelom, Rigbi, Bahir Sille, Malbug, Nahor Sile, Santipur, Hajong Bosti, Urang Bosti, Rabha Kathoni, Sonowal Kathoni, Berachapori, Beramilon, Beramajgoan, Taribosti, Luhijan and Bahirjonai (Fig.1).

The inhabitants of fringe villages belong to different ethnic groups such as Mising, Bodo, Rabha and Nepali, the Mising being the dominant tribe. Most elders are illiterate reflecting slow pace of educational development in the area. During field study we observed primary school in 20 villages, middle level in 5 villages and high schools in 2 villages. Modern healthcare is not adequate as only 4 villages have primary health center. Agriculture is the main occupation of the people supplemented with hunting, fishing and trade of minor forest products. Both men and women take active participation in livelihood activities but faming particularly tilling is considered as the domain of men. Livestock rearing is another important livelihood practice of the fringe communities; it brings cash income to the families through sale of cow, buffalo, goat, poultry, pigs, etc. Many families collect minor forest products and sell them in local markets to earn cash income. Some abled men and women work as daily wage laborer in and neighbouring villages, even in Jonai subdivisional town; some families own shop as part of diversif ication of livelihood strategies. 
Methodology: The present study was undertaken in Poba RF under Jonai sub-division of Dhemaji district, Assam during 2012 and 2013. Permission for conducting the study was obtained from local forest department. Verbal consent of household members of fringe villages of Poba RF for participation in the study was also obtained. Methods adopted for collecting data are briefly discussed below:

1. Interviews: For the present study 22 villages in fringe areas of Poba RF were selected. Data of human-wildlife conflicts for the period from 1971-2013 was collected through interview of household members and people affected by wild animals. Office staffs of forest department were interviewed on issue of anthropogenic activities in Poba RF and its implications on human-animal conflicts. We also interviewed villagers, forest off icials and NGOs regarding compensation provided to affected people.

2. Official records: Data on human-animal conflicts were also collected from official record maintained in the Forest Beat Off ice and Forest Range Off ice and compared with information recorded from inhabitants of fringe villages.

3. Personal observations: We visited the 22 villages during 2012-2013 for personal observations of loss or damage to crops/property/life caused by wild animals and forest encroached by fringe settlers. This helped us to corroborate (to the possible extend) information provided by villagers and forest department about incidents of humanwildlife conflicts.

We performed Pearson's correlation on variables such as wildlife killed/injured, livestock killed, property damaged and crop damaged to draw relationship among the variables. People attitude towards wildlife in Poba RF was evaluated from scoring of structured interview among farmers from ten villages, who have been exposed to humanwildlife conflict in the area for ten or more years. Ten years exposure to conflict is considered as this is a conceivable period for a person to develop attitude towards wild animals. We used harsh or fatal strategies (for example trap, fire, spears, etc.) adopted by farmers towards wildlife as proxy for assessment of their attitudes towards wildlife. Forest area encroached and used for agricultural activities was physically verif ied during field study. We calculated economic loss of farmers due to conflict based on structured interview.

\section{Results and Discussion:}

There is an increasing trend of human-wildlife conflict in Poba RF. Encroachment for agricultural expansion; frequent venturing into forests to collect minor products (fuel wood, fodder, food, medicines, etc) and livestock grazing are major factors leading to man-animal conflicts. In extreme cases there were casualties on both human and animals. Most cases of conflict occurred in crop fields and inside forest suggesting encroachment and venturing into animal habitat exposed human to conflict with wildlife. This supports our hypothesis that 'encroachment and frequent venturing into the forest' are the main drivers of humanwildlife conflicts in the study area. Wildlife caused considerable damage to crops and property resulting in food insecurity and economic loss to farmers; farmers also suffered economic loss due to livestock lifting by prey animals. Long term exposure to wildlife related 


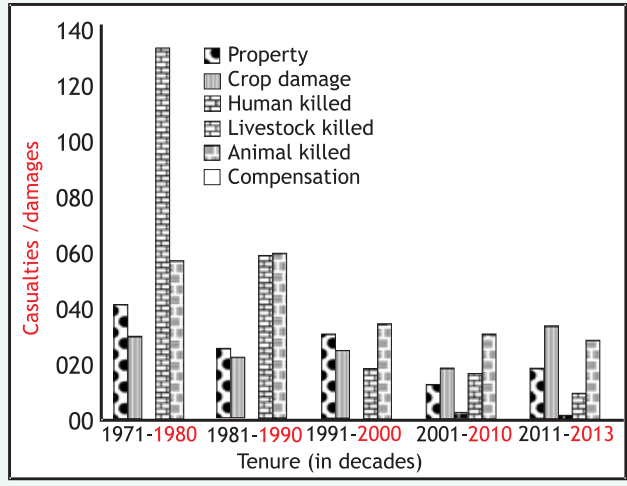

Fig.-2 Human-wildlife conflicts in Poba RF from 1971-2013

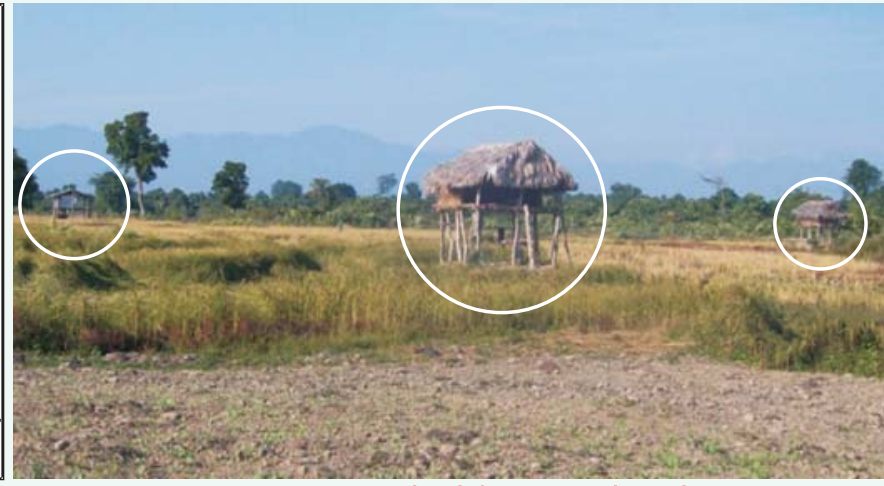

Fig.- 3: Forest area encroached for agricultural purposes; farmers make Tongi (temporary huts with raised platform) to guard their crops from wild animals, particularly elephants.

risks and economic loss are associated with negative attitude towards wildlife in Poba RF. The present report will serve as a reference on subsistence practices of fringe communities and the nature of conflicts. This information will be useful for local forest department in initiating appropriate conservation measures in Poba RF.

Chronology of human-animal conflict in Poba RF is presented in Figure 2. There was no human casualty from 1971 to 1990 but livestock killed by wild animal was as high as 190 and wild animals killed by human was 115. During 1991-2013 two persons were killed by wild animals; livestock killed by wild animals and wild animals killed by human came down to 42 and 92 respectively. Damages to property (i.e., house) during 1971-1990 was 75 (fully-30 houses, partially-35 houses) and crops field of 51 families were damaged. During 1990-2013 damage to property by animal was 60 (fully-25 houses, partially-35 houses) and crop fields of 75 families were damaged. Most cases of conflict occurred in forests and crop fields suggesting encroachment has brought more forest areas under human activities. These results proved our hypothesis that 'encroachment and frequent venturing into the forest' are major causes of human-wildlife conflicts in Poba RF. Record of alleged encroachment of forest area by fringe communities is not available with the local forest department but we visited encroached forest land, now converted into crop field, (Fig.3) for personal observation and assessment. Pearson's correlation of variables (Table 1) of human-wildlife conflict at 0.01 level of significance showed positive correlation between wildlife injured/killed and livestock killed/injured (o.819411) and wildlife injured/killed and property damaged (0.6580o9). these relationships indicate when herbivores including large mammals depredate farmers' crops there is equal chance of wildlife being injured/killed and when animals particularly elephants attack house, inmates may suffer injury and the latter in the effort to protect their houses injure the animals as well. Pearson's correlation between wildlife injured/killed and crop damaged showed negative relationship (-0.04104) at o.o1 level of significance, suggesting with intense defending and attack on wildlife, farmers were able to protect their crops. The variables of conflict in Poba RF showed cause and effect relationship. 
Table-1:. Pearson's correlation analysis of human-wildlife conflict in Poba Reserve Forest, Assam

\begin{tabular}{|c|c|}
\hline Variables & $\begin{array}{l}\text { Pearson } \\
\text { correlation }\end{array}$ \\
\hline wildlife injured/killed \& Livestock killed & $0.819411^{* *}$ \\
\hline wildlife injured/killed \& Property damaged & $0.658009^{* *}$ \\
\hline wildlife injured/killed \& Crop damaged & 0.04104 \\
\hline
\end{tabular}

\section{** Correlation signif icant at 0.01 (two-tailed)}

There is some margin of error in our analysis as most cases of conflicts are not reported probably for fear of being harassed by forest off icials. Further, data before 2012 was mainly based on interview of household members and victims of human-animal conflict. Based on information

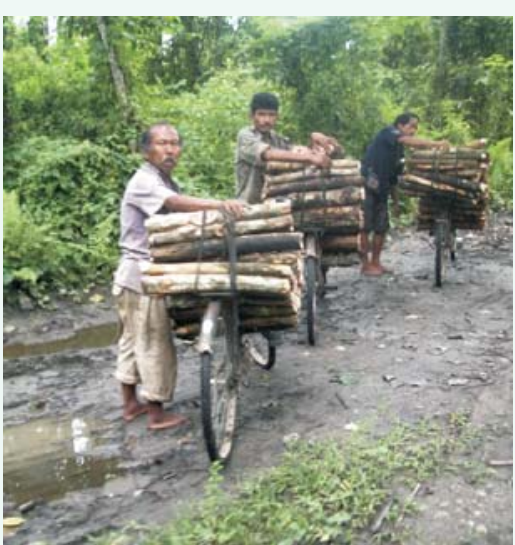

Fig. - 4: Three persons loaded fuel wood on bicycles from Poba $\mathrm{RF}$ and proceed to local market for selling the forest product.

Table-2: Animals responsible for loss of crops and livestock in fringe villages of Poba RF

\begin{tabular}{|c|c|c|c|c|}
\hline SNo & Animal & Family & Loss/Damage & Season \\
\hline 1 & Elephas maximus & Elephantidae & All crops & September toApril \\
\hline 2 & Panthera tigris & Felidae & Livestock & Round the year \\
\hline 3 & Sus scrofa & Suidae & $\begin{array}{l}\text { Arums, potato, sweet potato, paddy, } \\
\text { mustard, pea, maize, chili, sesame } \& \\
\text { rooting in cropf ields }\end{array}$ & May to February \\
\hline 4 & Macaca mulatta & Cercopithecidae & $\begin{array}{l}\text { Fruit plants, battle nut, paddy, sweet } \\
\text { potato, pea and maize }\end{array}$ & September to April \\
\hline 5 & Cervus duvaucelii & Cervidae & $\begin{array}{l}\text { Sweet potato, paddy, mustard, pea, } \\
\text { sesame, maize, chili. }\end{array}$ & August. to March \\
\hline 6 & Axis porcinus & Cervidae & $\begin{array}{l}\text { Sweet potato, paddy, mustard, pea, } \\
\text { sesame, maize, chili }\end{array}$ & August to March \\
\hline 7 & Muntiacus muntjak & Cervidae & $\begin{array}{l}\text { Sweet potato, paddy, mustard, pea, } \\
\text { sesame, maize, chili }\end{array}$ & August to March \\
\hline 8 & Lepus nigricollis & Leporidae & $\begin{array}{l}\text { Sweet potato, paddy, mustard, pea, } \\
\text { sesame, maize, chili }\end{array}$ & August to March \\
\hline 9 & Caprolagus hispidus & Leporidae & $\begin{array}{l}\text { Sweet potato, paddy, mustard, pea, } \\
\text { sesame, maize, chili }\end{array}$ & Round theyear \\
\hline 10 & Hystrix sp. & Hystricidae & $\begin{array}{l}\text { Sweet potato, paddy, mustard, pea, } \\
\text { sesame, maize, chili }\end{array}$ & Round theyear \\
\hline 11 & Funambulus pennanti & Sciuridae & Fruit plants. & Round theyear \\
\hline 12 & Psittaculasp. & Psittacidae & Paddy, maize, mustard, fruit plants. & Round theyear \\
\hline 13 & Columbia livia & Columbidae & Mustard, paddy, maize & $\begin{array}{l}\text { September,October } \\
\text { \& February to April }\end{array}$ \\
\hline 14 & Streptopelia chinensis & Columbidae & Mustard, paddy. & $\begin{array}{l}\text { September,October } \\
\text { \& February to April }\end{array}$ \\
\hline 15 & Canis bengalensis & Canidae & Livestock & Round theyear \\
\hline 16 & Felis chaus & Felidae & Livestock & Round theyear \\
\hline
\end{tabular}


provided by villagers and forest officials we identified 16 animals responsible for crops damages in the region (Table 2). Data of compensation provided by Govt./NGO to affected people was inadequate. We found most cases of conflict were not reported for reason stated above; some families have reported nonpayment of compensation even in genuine cases of conflicts as the reason for not informing the forest department.

Habitat overlap due to encroachment for agricultural expansion (Fig.3) and frequent venturing into forests to collect minor products (Fig.4) have been observed as major factors leading to man-animal conflicts in Poba RF. Activities of animals particularly elephants, monkeys, porcupine and wild boars are more prominent during agricultural season when they come out of their natural habitats to feed on crops cultivated by farmers of fringe villages. Crop raiding by elephants is particularly significant as it involves risk to human lives and the magnitude of damage to crops and property is far greater as compared to other animals. A few bird species (Table-1) are also potent agricultural pest in the study area. Dependence on forest products demands visit into the forest to collect minor products for food, medicines, fibres, construction and livelihoods. These activities bring fringe inhabitants into direct conflict with wild animals.

It may be mentioned that elephants use the Poba RF as corridor between the Daying Ering Wildlife Sanctuary in Arunachal Pradesh and Dibru-Saikhowa National Park via proposed Kobu Chapori Reserve Forest. At night elephants from the forest venture into the fringe villages in search of standing crops, paddy in granary and bananas of home gardens. The animals come under intense resistance from human who are determined to protect their
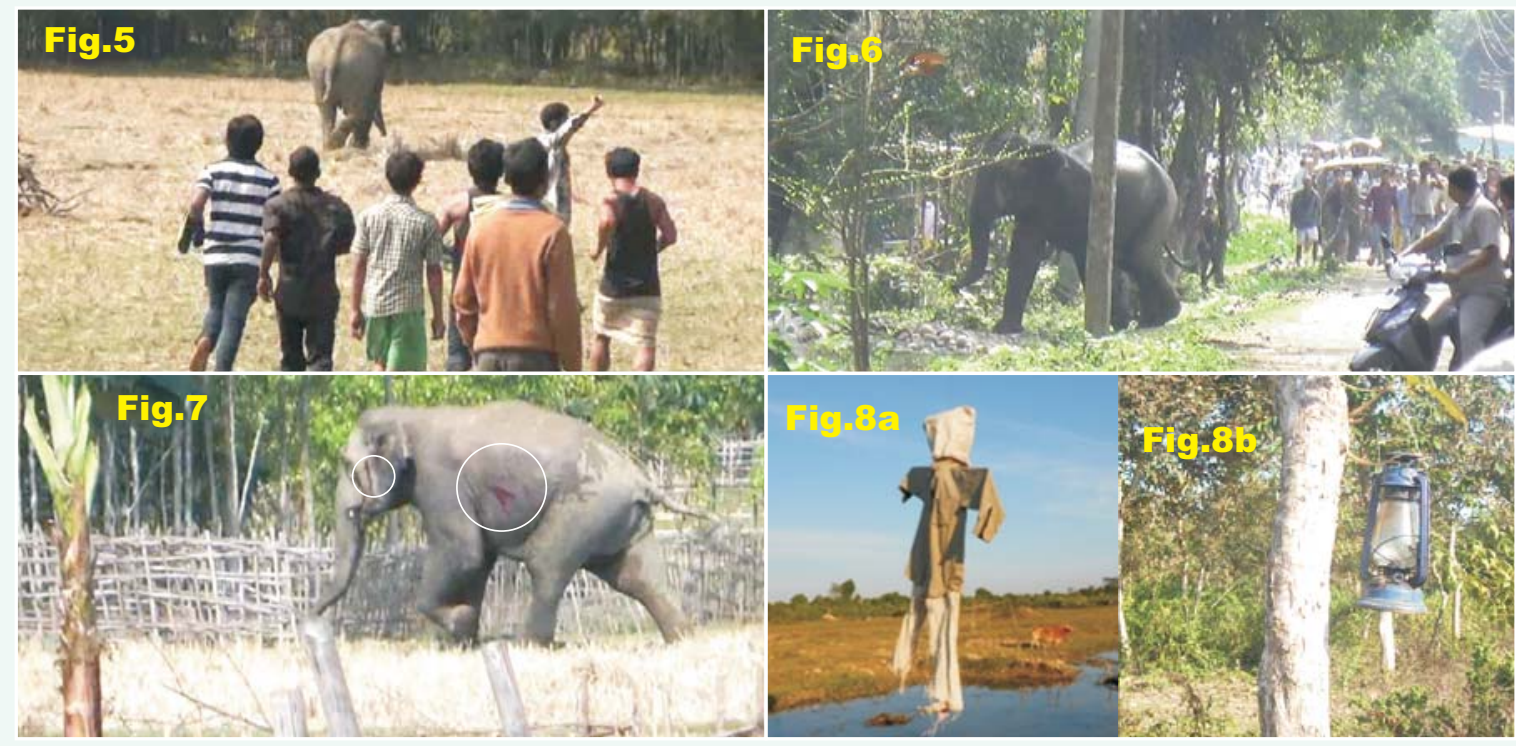

Fig.-5: People are seen chasing an elephant that had foraged and damaged farmers' crop.

Fig.-6: A herd of elephant strayed into Jonai town in broad daylight; an elephant of the herd search for escape route when chased by residents. Fig.- 7: An elephant injured by residents for raiding crops. Fig.-8: a) Lamp and b)effigy of human are placed on the edge of crop fields bordering Poba RF to deter elephants from raiding crops. 
homes and crops. Villagers do not hesitate to use any weapons they can lay their hands on like spears, bow and arrow and fire to drive away elephants. Though we found no report of elephant's death due to conflict, injury to these large mammals are inevitable considering the strategies and nature of weapons used by them. Besides, we found cultural practices of fringe villagers also contributed to conflicts leading to loss of property and sometimes human lives. People of the fringe villages often make rice beer called Apong (or sulai mod) for consumption in daily life. Elephants, monkey, wild boar and domestic animals like cattle and goat are fond of this fermented food. Elephants get attracted by the aroma of Apong and in search the food bring down houses which sometimes inflict casualties to household members.

Wild boars are next to elephants in causing damage to cultivated plants. They are nocturnal and often forage on paddy and tuberous crops like yams, cassava, aroids and sweet potato. Rooting behavior of the animal caused considerable damage to crops and soil. Being highly active and sensitive, wilds boars raid crops without being noticed by farmers. For this, the animals are trapped or poisoned with pesticides or herbicides. Wild boars are regularly hunted for its meat as well. Other animals like monkeys, squirrels, hog deer, barking deer, swamp deer, Indian hare and hispid hare raid and damage fruits plants, paddy, sweet potato, mustard, pea and maize in the fringe villages. Porcupine (Hystrix sp.) also feed on cultivated plants but the animal is hunted for other purposes too. Whole intestine is popular ethnomedicine for dysentery and constipation; their quills are used by tribal women to prepare the warp for weaving in back strap loom. Prey animals like tiger, leopard and fox come in conflict with man for lifting livestock; the intensity of conflicts however, is less when compared with crop raiding animals.

Farmers in fringe villages of Poba RF adopt many strategies aimed at preventing animals from foraging and damaging crops. For example, to repulse elephants, people would burst firecrackers, shout or beat drums while others throw stones and sharp weapons at them. Some farmers would carry torch (a piece of cloth wrapped at the end of stick, soaked in inflammable substance and ignited) locally referred as Me'ru to frighten raiding elephants. Still further, some residents would even pierce red hot iron into the flesh of the animals with the help of bamboo pole. In panic, the elephant herd breaks into smaller groups and in the effort to find escape route some men come in front of the elephant and get killed or injured (Fig. 5-7). Most attacks by elephants are provoked. During crop season farmers would form groups and make watch tower called Tongi which are temporary tree houses (Fig. 3). Additionally, farmers place lamps and eff igy of human on the edge of paddy fields bordering Poba RF (Fig. 8); this is done to remind raiding animals of human presence and deter them from visiting the crop field. Farmers also set traps (sitika) for small animals like porcupine, wild boar and rabbit; some villagers put sharp tools like nails and pointed objects to injure elephants; this is said to deter the animals from visiting crop fields again. Some farmers have reported use of pesticides or herbicides to poison crop pests like small vertebrates and birds. Conflict with wild boars also occurs during mating season of the latter. Male boars become most aggressive during this period and charge at humans and other animals that trespass 
their territory. Monkeys attack children and women but they retreat, when male members intervene. Porcupines shoot with their quills when threatened by predators including human.

Table 3: Assessment of people attitude towards and economic loss due to wildlife in Poba RF

\begin{tabular}{|lllc|}
\hline Village & Measuresadopted against wildlife & Nature of economic loss & Year \\
\hline Sirung & Trap, spear, fireand pesticides/herbicides & Crops, house, poultry, cow, goat, duck & $10-20$ \\
Leku & Trap, spear, fire, pesticides/herbicides & Crops, house, poultry, cow, goat, duck & $10-40$ \\
Leku Jelom & Trap, spearand fire & Crops, house, poultry, cow, goat, duck & $10-44$ \\
NaharJelom & Trap, spear, fireand pesticides/herbicides & Crops, house, poultry, cow, goat, duck & $15-25$ \\
Rigbi & Trap, spearand fire & Crops, house, poultry, cow, goat, duck & $10-35$ \\
Malbuk & Trap, spearand fire & Crops, house, poultry, cow, goat, duck & $15-25$ \\
Santipur & Trap, spear, fireand pesticides/herbicides & Crops, house, poultry, cow, goat, duck & $15-20$ \\
Rabhakathoni & Trap, spearand fire & Crops, house, poultry, cow, goat, duck & $15-22$ \\
Taribosti & Trap, spearand fire & Crops, house, poultry, cow, goat, duck & $15-22$ \\
Bahirsille & Trap, spear, fireand pesticides/herbicides & Crops, house, poultry, cow, goat, duck & $25-40$ \\
\hline
\end{tabular}

*Year of exposure to conflict (average)

Local people's attitude towards wildlife was evaluated based on structured interview of residents who have been exposed to wildlife conflict for not less than ten years. Ten years is a conceivable period for people to develop attitude towards wildlife. Methods adopted by farmers which are capable of causing injury or death or capture of animals and ssocioeconomic loss were used as indicators of negative attitude of fringe communities towards wildlife. All farmers (four members each from ten villages) interviewed responded positive towards use of traps, spears and fire (Table 3 ) and also expressed no hesitation in using any harsh means if it helps in protecting their crops, property and livestock. Farmers in five villages reported use of pesticides/herbicides against birds and small vertebrates. All farmers expressed similar view that injuring animals frighten and deter them from visiting the site (crop field, house, etc) again. Long years of exposure to crop and property loss and risk to life from wildlife are associated with negative attitude towards wildlife; adoption of harsh strategies against animals amply reflects this trend.

Humanwildlife conflicts in Poba RF have significant socio-economic dimensions (Table 3). Crop damage due to wildlife and predation on livestock by prey animals has created signif icant financial losses and hardship to farmers. Forest products and livestock are other important means of livelihoods in fringe villages of Poba RF. Income from selling forest products and livestock like poultry, pigs and goats help them procure food, medicines and other household commodities. Elephants caused maximum loss by foraging and trampling standing crops. Farmers have suffered decline in the production of taro (Colocasia esculanta), potato (Solanum tuberosum), sweet potato (Ipomoea batatas), paddy (Oryza sativa), mustard (Brassica compestris), pea (Pisum sativum), maize (Zea mays), chili (Capsicum spp.) and sesame (Sesamum indicum) due to depredation by wild boars and porcupine. Boars are responsible for rooting around agricultural fields which often invited the wrath of farmers leading to death of the animal through poisoning and trapping. Monkeys, rodents, birds, hog deer, barking deer, swamp deer, Indian hare and hispid hare are 
recognized pest of paddy, maize, pea, mustard and sweet potato, causing considerable economic loss to farmers. Monkeys being more active among other animals are more prone to conflict as, often farmers would chase crop raiding monkeys with dogs and kill/injure them or poison them with pesticides/herbicides.

\section{Conclusion:}

Human-wildlife conflict in Poba RF is a contentious issue with socio-economic implications on one hand and conservation on the other hand. Information gathered during our study reflected decreasing trends in human casualties but ground reality show unabated encroachment resulting in further penetration into animal habitat. This decline (human casualties) might be due to negative attitudes developed by residents of fringe villagers towards wildlife, particularly against elephants, that often put the animal at the receiving ends with grave injury. Human atrocities may have influenced elephants to avoid fringe villages and cross over to the Daying Ering sanctuary in Arunachal Pradesh to look for food and shelter. Largely the conflicts in Poba RF are for food and livelihoods of fringe villagers. So initiatives to mitigate conflicts and conservation of wildlife need a holistic approach by considering subsistence practices and involvement of local community in management practices. Imparting environmental education and awareness about the value of wildlife can also contribute in developing positive mindset among the fringe inhabitants. Also, being an important elephant corridor, the Poba RF needs to be prioritized for conservation. Further, the present report on human-wildlife conflict in the reserved forest will help forest department for undertaking appropriate mitigation strategies and conservation of Poba RF.

\section{Acknowledgements:}

Authors are thankful to the fringe villagers of the Poba RF for their participation in the present study and for sharing their knowledge, information and experience. Authors thank Forest Department for granting permission to undertake study the protected area.

\section{References}

Arjunan M., Holmes C., Puyravaud J.P. \& Davidar P. (2006).. Do developmental initiatives influence local attitudes toward conservation? A case study from the Kalakad-Mundanthurai Tiger Reserve, India. J. Environ. Manag., $79(2): 188-197$

Borah J., Thakuria K., Baruah K.K., Sarma N.K. \& Deka K (2005):. Man-Elephant Conflict Problem: A Case Study. Zoos' Print, 20(7):22-24.

Distefano E. (2005):.Human-Wildlife Conflict Worldwide: collection of case studies, analysis of management strategies and good practices . Published Report. FAO, Rome.

Erkinaro E., Kalevi H., Lindgren E. \& Sulkava S. (1982):. Occurrence and spread of wild pigs (Sus scrofa) in the eastern Fenno Scandia. Memoranda, 58:39-47

Fadeev E.V. (1981):. Dynamics of the northern limits of the area of distribution of the wild boar, Sus scrofa in Eastern Europe. Biol. Nauk. (Mosc.), O(9): 56-64

Hoare R. (2000):. African elephants and humans in conflict: the outlook for coexistence. Oryx, 34:34-38.

Karanth K.K., Gopalaswamy, A.M., Prasad, P.K. \& Dasgupta, S. (2013):. Patterns of humanwildlife conflicts and compensation: Insights from Western Ghats protected areas. Biol. Conserv., 166:175-185.

Lamarque F., Anderson, J., Chardonnet, P., Fergusson, R., Lagrange, M., Osei-Owusu, Y., Bakker, L., Belemsobgo, 
U., Beytell, B., Boulet, H., Soto, B. \& Tabi Tako-Eta, P. (2008): Human-Wildlife Conflict in Africa- An Overview of Causes, Consequences and Management Strategies. Working Paper of IFCW and FAO, Rome.

Linkie M., Dinata Y., Nofrianto A. \& Leader-Williams N. (2007):. Patterns and Perceptions of wildlife crop raiding in and around Kerinci Seblat National Park. Sumatra Animal Conservation, 10:127-135.

Naughton-Treves L. (1998):. Predicting patterns of crop damage by wildlife around Kibale National Park, Uganda. Conserv. Biol., 12:156-168.

Naughton-Treves L. \& Treves A. (2005): Socio-ecological factors shaping local support for wildlife: Crop-raiding by elephants and other wildlife in Africa. In: People and wildlife: Conflict or coexistence? R. Woodroffe, S. Thirgood \& A. Rabinowitzeds., 252-277. New York: Cambridge University Press.

Patel D. \& Dharaiya N. (2014): Human-wildlife conflicts in arid areas of Western India: strategies for mutual coexistence. Ambient Science, 1(1):29-37.

Pegu R., Gogoi J., Tamuli A.K. and Teron R. (2013):. Ethnobotanical study of wild edible plants in Poba Reserved Forest, Assam (India): multiple functions and implications for conservation. Research Journal of Agriculture and Forestry Sciences, 1(3):1-10.

Riley S.J. \& Decker D.J. (2000): Wildlife stakeholder acceptance capacity for cougars in Montana. Wildlife Society Bulletin, 28:931-939.

Sillero-Zubri C. \& Switzer D. (2001): Crop raiding primates: searching for alternative human ways to resolve conflict with farmers in Africa. Publisher: People and Wildlife Initiative Wildlife Conservation Research Unit, Oxford University.

Sukumar R. (1994): Wildlife-human conflicts in India: an ecological and social perspective. In: Social Ecology, Guha, R. ed., pp.303-317, Oxford University, New Delhi.

Tisdell C.A. (1982): Wild pigs: Environmental Pest or Economic Resource, pp. 445, Pergamon Press: Sydney.

Treves A., Wallace R.B. \& White S. (2009):. Participatory planning of interventions to mitigate humanwildlife conflicts. Conserv. Biol. 23:1577-1587.

Woodroffe R., Thirgood S. \& Rabinowitz A. (2005):. People and Wildlife, Conflict or Coexistence? Cambridge University Press, Cambridge, UK. World Park Congress.

WPC (World Park Congress) recommendation 20. (2003): Preventing \& mitigating human-wildlife conflicts. Publisher: IUCN, Rue Mauverney 28, Switzerland. 